\title{
Inheritance of spontaneous mutant homostyles in Turnera subulata $\times$ krapovickasii and in autotetraploid T. scabra (Turneraceae)
}

\author{
F Tamari, D Khosravi ${ }^{1}$, AJ Hilliker and JS Shore \\ Department of Biology, York University, 4700 Keele Street, Toronto, Ontario, Canada M3J 1P3
}

\begin{abstract}
To explore the genetic architecture of distyly in Turnera spp., we determined the inheritance and compatibility behaviour of two spontaneous homostyled mutants. A long-homostyled mutant shoot arose on an otherwise short-styled plant that was an artificial hybrid (Turnera subulata $\times T$. krapovickasii) between two diploid distylous species. The mutation appears to be an allele, $S^{H}$, of the distyly locus with the dominance relationships, $S>S^{H}>S$, where $S$ confers the short-styled phenotype, $S^{H}$ confers homostyly in $S^{H} S^{H}$ and $S^{H} S$ genotypes, and ss genotypes are long-styled. Aberrant segregation ratios were observed among some crosses and might be the result of pollen competition. Compatibility relationships are consistent with the hypothesis that a gene complex determines distyly. Infrequently, revertant short-styled flow-
\end{abstract}

ers have appeared on cuttings of the $T$. subulata $\times T$. krapovickasii mutant and on occasion, short-styled progeny have appeared in crosses where none were expected. A second mutant homostyle was discovered in autotetraploid $T$. scabra. The mutation is inherited as above, however, tetrasomic inheritance occurs at the locus. This homostyled mutant carries two copies of the $S^{H}$ allele and has the duplex genotype $S^{H} S^{H} S S$. Compatibility relationships were as observed above. The occurrence of homostyled mutants is consistent with the hypothesis that a linked gene complex underlies the inheritance of distyly in Turnera but we cannot discount the hypothesis that an allelic series is responsible. Heredity (2005) 94, 207-216. doi:10.1038/sj.hdy.6800599 Published online 13 October 2004

Keywords: Turnera; tetrasomic inheritance; distyly; homostyly; self-incompatibility

\section{Introduction}

Distyly is a plant breeding system in which long- and short-styled morphs occur at approximately equal frequencies in natural populations. The morphs differ in having a reciprocal positioning of reproductive organs and are typically self- and intramorph incompatible. A number of ancillary dimorphisms, such as those of pollen size and pollen production, commonly occur (Dulberger, 1992). Distyly has arisen independently at least 28 times within the angiosperms (Arroyo and Barrett, 2000) and appears to be inherited as a single locus with two alleles (Lewis and Jones, 1992). Work on Primula spp., however, indicates that distyly is actually controlled by a linked gene complex or supergene (Figure 1). Various authors have suggested that three to seven tightly linked loci account for the dimorphisms distinguishing the long- vs short-styled morphs (Ernst, 1955; Dowrick, 1956; Lewis and Jones, 1992; Kurian and Richards, 1997; Richards, 1997).

One approach to discovering the genetic architecture of distyly is to investigate the inheritance of novel floral and/or incompatibility phenotypes that have arisen either through mutation (spontaneous or induced) or

Correspondence: JS Shore, Department of Biology, York University, 4700 Keele Street, Toronto, Ontario M3I 1P3, Canada. E-mail: shore@yorku.ca ${ }^{1}$ Current Address: Institute of Molecular Medicine and Genetics (IMMAG), Medical College of Georgia, 1120 15th Street, Augusta, Georgia 30912-2600, USA.

Received 16 February 2004; accepted 3 September 2004; published online 13 October 2004 recombination. Under the three locus model (Figure 1) for the supergene determining distyly in Primula (Lewis and Jones, 1992), it should be possible to 'knockout' each of the dominant alleles in short-styled plants by generating mutations. The mutations should map to the distyly locus, and a predictable set of morphological and compatibility phenotypes should emerge from such an analysis (Figure 1). If a linked gene complex underlies the genetic architecture of distyly, a better approach would require observations of novel floral morphs that emerge from compatible crosses via recombination. This would, unfortunately, require very large sample sizes, and that genetic markers that lie outside the putative gene complex are available to confirm the recombinational (rather than mutational) origin of the novel phenotypes.

Distyly is widespread within the Turneraceae and exhibits features common to most distylous species. Shore and Barrett (1985) studied the inheritance of distyly in diploid and autotetraploid Turnera subulata and T. scabra ( $=$ T. ulmifolia var. elegans and T. ulmifolia var. intermedia, respectively). They showed that distyly appeared to be determined by the usual one-locus diallelic system. In diploids, short-styled plants were heterozygous, Ss (although homozygous dominant, SS, genotypes that were short-styled, were produced via selfing), while long-styled plants were homozygous recessive, ss. For autotetraploids, short-styled plants were simplex, Ssss, while long-styled plants were nulliplex, ssss. Short-styled plants that were duplex, SSss, were generated and used in crosses to demonstrate 


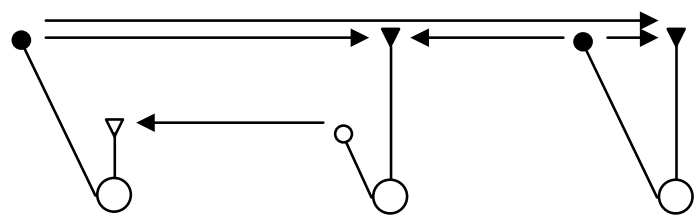

$\begin{array}{lccc}\text { Morph } & \text { Short } & \text { Long } & \text { Homostyle } \\ \text { Allelic series } & S \text { - } & \text { ss } & S^{H} \text { s or } S^{H} S^{H} \\ \text { Gene complex } & \text { GPA/--- } & \text { gpa/gpa } & g^{*} P A / g p a \text { or } g^{*} P A / g^{*} P A\end{array}$

Figure 1 Relative lengths of styles and stamens for long-, short- and homostyled plants. Arrows indicate compatible pollinations. The genotypes of plants are provided under two models of inheritance; (1) an allelic series; (2) a gene complex where G/g determines style length and its incompatibility $P / p$ determines pollen size and pollen incompatibility, and $A / a$ determines style length.
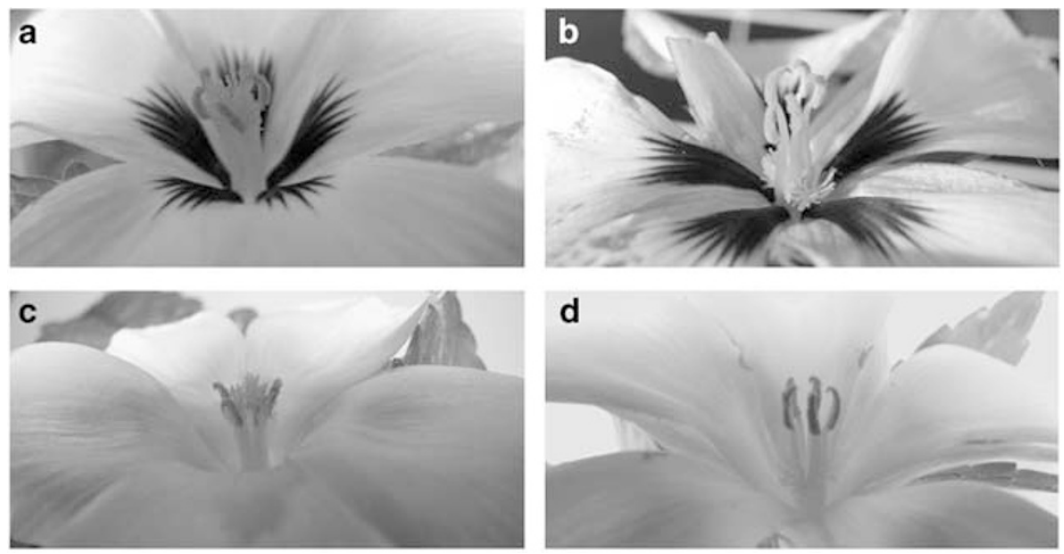

Figure 2 Photographs of flowers. (a) T. subulata $\times$ T. krapovickasii Mhomo-H homostyle mutant. (b) T. subulata short-styled. (c) T. scabra Drh homostyle mutant. (d) T. scabra short-styled.

tetrasomic inheritance (Shore and Barrett, 1985). Tetrasomic inheritance in these species was also demonstrated at isozyme loci (Shore, 1991a, b).

Homostylous self-compatible species also occur in the genus Turnera (Barrett and Shore, 1987). Compatibility relationships determined by controlled pollinations among distylous and homostylous species, as well as the ratios of progeny phenotypes from these crosses, were consistent with the possibility that distyly is determined by a linked gene complex (Figure 1), but by no means proves this to be the case (Shore and Barrett, 1985; Barrett and Shore, 1987; Tamari et al, 2001).

We have never observed any homostyled individuals in natural populations of distylous Turnera species, or until recently, among progeny grown under glasshouse conditions. Distylous and homostylous populations are known to occur in Piriqueta morongii (Turneraceae), but the inheritance of distyly and homostyly is unknown in that species (MM Arbo and JS Shore, personal observations).

Here, we exploit the occurrence of two spontaneous homostyle mutants to investigate the genetic architecture of distyly. We do so by using the gene complex model as a working hypothesis for the genetics of distyly in Turnera (Figure 1). Predictable phenotypes, compatibility relationships and inheritance patterns emerge from this model, which we test by characterising the morphology, compatibility behaviour and inheritance of the mutants.
One mutant appeared as a 'sport' in August 1998, on an otherwise short-styled plant (Figure 2a, b) from a cross between two diploid distylous species (T. subulata $\times T$. krapovickasii). One plant, approximately 1 year in age, began producing long-homostyled flowers (flowers with long stamens and long styles, which we shall refer to as homostyled for convenience) on a single branch. A second homostyled mutant first flowered in November 2002 (Figure 2c, d). It appeared as a seedling growing out of a pot of a short-styled autotetraploid plant of T. scabra. We believe these mutants to be the only spontaneous mutations to homostyly reported in the Turneraceae. The results bear upon both the genetic architecture of distyly in Turnera and the origins of homostylous species in the genus.

\section{Materials and methods}

\section{Crosses, isozyme assays and morphological measurements}

Crosses were performed using fine forceps, transferring pollen from one or more anthers. Forceps were rinsed in ethanol and wiped dry between pollinations. Selfcompatible plants were emasculated 1 day prior to anthesis to prevent self-pollen contamination. Seeds were collected by wrapping capsules in parafilm and were then harvested upon capsule dehiscence. Seeds 
were sown and germinated as described elsewhere (Shore and Barrett, 1985). Electrophoretic methods followed those in Athanasiou and Shore (1997). Progeny were scored for floral phenotype (long-styled, shortstyled or homostyled). We measured style length and stamen length from the base of the ovary, using callipers. The length of freshly collected pollen (five arbitrarily chosen pollen grains per flower) was measured using a compound microscope with a calibrated ocular micrometer. We determined pollen viability (stainability) using aniline blue in lacto-phenol staining and scoring the first 300 pollen grains encountered per flower.

To denote plants used in various crosses, we use the letter ' $\mathrm{K}$ ' to describe plants of $T$. krapovickasii, ' $\mathrm{S}$ ' for $T$. subulata and 'DR' for plants of T. scabra from the Domincan Republic. Each plant is given a number and is usually followed by a letter indicating its morph ( $\mathrm{S}=$ short-, $\mathrm{L}=$ long-, $\mathrm{H}=$ homostyled). Some plants were given longer codes (eg Mhomo-H, Drh, Bry), and these are described elsewhere. To denote progeny used for further crosses (eg for test crosses), their parentage is indicated in the code used to describe them. For example, the plant $\mathrm{K} 12 \mathrm{Lmho}-4 \mathrm{H}$, is a homostyled progeny individual obtained from the cross of K12L $\times$ Mhomo-H. For all crosses, the female (ovule) parent is always listed first.

\section{Compatibility behaviour}

To investigate compatibility of the mutant hybrid homostyle, Mhomo-H, which sets few seeds as a result of high levels of seed abortion, we self-pollinated it, and crossed it reciprocally, to long- and short-styled plants of both T. krapovickasii and T. subulata. Styles were fixed $24 \mathrm{~h}$ after pollination and pollen tube growth was assessed using aniline blue staining and fluorescence microscopy following Tamari et al (2001). For each pollinated style, we measured style length from the base of the style, we determined whether or not pollen tubes had reached the base of the style, measured the length of the longest pollen tube and the distance to which the majority of pollen tubes had grown. For the mutant homostyle of $T$. scabra, we carried out reciprocal pollinations to long- and short-styled plants of T. scabra and counted seeds set per pollination to assess compatibility behaviour.

\section{Statistical analyses}

We used the G-statistic to assess goodness of fit and heterogeneity for segregation data. Recombination frequencies between the distyly and Aco-1 loci were obtained using maximum likelihood estimation, and heterogeneity among estimates was assessed using a $\chi^{2}$ statistic (Allard, 1956). Means for various characters were compared using analysis of variance (ANOVA) followed by Scheffe's test for multiple comparisons. The latter analyses were carried out using SAS (1996) or SPSS (1997) statistical packages.

\section{Results}

\section{Parental genotypes}

The first homostyled mutant arose from the cross $T$. subulata $\times$ T. krapovickasii (for convenience we refer to this hybrid plant as Mhomo-H and the nonmutant that gave rise to it as Mhomo-S). The female parent used in the
Table 1 Genotypes of plants used in crosses

\begin{tabular}{|c|c|}
\hline Plant & Genotype \\
\hline Bry & $P g d-c^{F} S A c o-1^{S} / P g d-c^{S} s$ Aco- $1^{F}$ \\
\hline K5S & $P g d-c^{S} S A c o-1^{M} / P g d-c^{S} S A c o-1^{F}$ \\
\hline Mhomo-H & Pgd-c $c^{S} s$ Aco- $1^{F} / P g d-c^{S} S^{H}$ Aco- $1^{N}$ \\
\hline S4L & $P g d-c^{S} s$ Aco-1F/Pgd-c $c^{S} s$ Aco- $1^{F}$ \\
\hline S16L & $P g d-c^{S} S A c o-1^{F} / P g d-c^{S} S$ Aco- $1^{F}$ \\
\hline $\mathrm{K} 12 \mathrm{~L}$ & $P g d-c^{S} s$ Aco- $1^{M} / P g d-c^{S} s$ Aco- $1^{F}$ \\
\hline K21L & $P g d-c^{S} S A c o-1^{F} / P g d-c^{S}$ s Aco- $1^{F}$ \\
\hline
\end{tabular}

Genotypes at the distyly locus, $A c o-1$ and $P g d-c$, are provided. $P g d-c^{F}$ and $P g d-c^{\mathcal{S}}$ are alleles encoding fast- and slow-migrating allozymes of cytosolic 6-phosphogluconate dehydrogenase, Aco-1F, Aco-1 M and $A c o-1^{S}$ are alleles encoding fast-, intermediate-, and slowmigrating allozymes of aconitase-1, and $S, s$ are two alleles of the distyly locus. $S^{H}$ is a putative mutant allele of the distyly locus determining the homostyled phenotype.

cross (termed Bry) is a cryptically self-incompatible short-styled plant of $T$. subulata. Using this parental plant (Bry), we have demonstrated that the distyly locus is flanked, on either side, by two isozyme loci (Shore and Barrett, 1986; Athanasiou and Shore, 1997). Bry is heterozygous at the distyly locus, as well as the aconitase-1 and cytosolic 6-phosphogluconate dehydrogenase loci (Table 1). The pollen parent for this hybrid cross was a short-styled plant of T. krapovickasii (K5S). Unfortunately, the pollen parent died shortly after the pollinations were made. Based upon floral morphology and isozyme assays of the progeny from the cross of this plant with Bry, it was possible to infer its genotype (Table 1). The Aco- ${ }^{M}$ allele it possessed is polymorphic in T. krapovickasii and the allozyme it encodes migrates to an intermediate position between allozymes encoded by the $A c o-1^{F}$ and $A c o-1^{S}$ alleles, using starch gel electrophoresis.

The Mhomo-H mutant obtained the recessive s-allele of distyly and the linked allele, Aco- $1^{F}$, from Bry ( $T$. subulata), while it received the $S$-allele (or its putative mutated form, $S^{H}$ ) and the linked allele, Aco- $1^{M}$, from $T$. krapovickasii (Table 1). We have used a number of other plants in crosses. Two long-styled plants (S4L and S16L) were obtained by selfing the short-styled plant, Bry. Both of these long-styled plants are homozygous at the three linked loci (Table 1). Two long-styled plants (K12L and $\mathrm{K} 21 \mathrm{~L}$ ) of $T$. krapovickasii were also used in crosses (Table 1).

\section{Origin of Mhomo-H}

From a cross of two short-styled plants (T. subulata $\times T$. krapovickasii), we obtained 16 short- and four long-styled progeny, which did not differ significantly from the expected 3 short: 1 long ratio $(G=0.28, P>0.05)$. A single shoot on one of these short-styled hybrid progeny produced homostyled flowers bearing long styles and long stamens (Figure 2a). We have propagated cuttings of both the mutant homostyle and nonmutant shortstyled shoots of this plant. On two occasions, cuttings made from the mutant shoot have produced shoots bearing a small number of short-styled flowers.

\section{Phenotype and compatibility behaviour of Mhomo-H}

The mutant, Mhomo-H, does not differ in stamen length or pollen size compared to the short-styled plant 
Table 2 Morphological measurements for Mhomo-H and Mhomo-S

\begin{tabular}{lcccc}
\hline & Pollen length $(\mu \mathrm{m})$ & Pollen fertility $\%$ & Style length $(\mathrm{mm})$ & Stamen length $(\mathrm{mm})$ \\
\hline Mhomo-H & $82.3(0.8)$ & $50.2(2.3)$ & $10.9(0.1)$ & $10.9(0.1)$ \\
Mhomo-S & $82.4(0.7)$ & $65.1(1.8)$ & $5.6(0.4)$ & $10.7(0.4)$ \\
F-value & $0.1 \mathrm{~ns}$ & $157.5^{* * *}$ & $968.6^{* * *}$ & $0.7 \mathrm{~ns}$ \\
\hline
\end{tabular}

***P<0.001.

Mean (SD) pollen size, percent fertility and style and stamen lengths (measured from the base of the ovary) for six replicate flowers from the spontaneous mutant and nonmutant (Mhomo-H and Mhomo-S) T. subulata $\times$ T. krapovickasii. F-values from ANOVA are provided.

Table 3 Compatibility relationships of the Mhomo-H mutant homostyle

\begin{tabular}{lccccc}
\hline Cross & $\mathrm{N}$ & No. of styles with tubes at base & Style length $(\mathrm{mm})$ & Majority of tubes $(\mathrm{mm})$ & Longest tube $(\mathrm{mm})$ \\
\hline Mhomo-H self & 20 & 20 & $9.93(0.4)$ & $9.93(0.4)^{\mathrm{a}}$ & $9.93(0.4)^{\mathrm{a}}$ \\
Mhomo-H $\times$ Bry & 20 & 20 & $9.33(0.5)$ & $9.33(0.5)^{\mathrm{a}}$ & $9.33(0.5)^{\mathrm{a}}$ \\
Mhomo-H $\times$ T. sub L & 20 & 0 & $9.43(0.6)$ & $2.83(0.6)^{\mathrm{b}}$ & $3.43(0.7)^{\mathrm{b}}$ \\
T. sub L $\times$ Mhomo-H & 20 & 16 & $10.53(0.4)$ & $9.03(3.1)^{\mathrm{a}}$ & $9.03(3.0)^{\mathrm{a}}$ \\
T. krp L $\times$ Mhomo-H & 20 & 20 & $6.13(0.7)$ & $10.13(0.7)^{\mathrm{a}}$ & $10.13(0.7)^{\mathrm{a}}$ \\
Bry $\times$ Mhomo-H & 25 & 6 & $4.7(0.3)$ & $1.53(1.1)^{\mathrm{bc}}$ & $2.63(2.0)^{\mathrm{b}}$ \\
T. krp S $\times$ Mhomo-H & 20 & 0 & - & $233^{* * *}$ & $0.43(0.5)^{\mathrm{c}}$ \\
F-value & & - & & $162^{* * * *}$
\end{tabular}

$* * * P<0.001$.

Pollen tube growth in styles involving crosses among the mutant Mhomo-H with long- and short-styled plants of T. subulata (T. sub), T. krapovickasii (T. krp) and a self-compatible short-styled plant of T. subulata (Bry). Number of styles examined ( $N$ ), number of styles with pollen tubes at the base, mean (SD) length of style, distance traversed by the majority pollen tubes and the longest tube are provided. Means sharing the same superscript are not significantly different following Scheffe's test $(P<0.05)$. $F$-values from a one-way ANOVA are provided.

Table 4 Morph ratios for crosses involving Mhomo-H

\begin{tabular}{|c|c|c|c|c|c|c|}
\hline Cross & & Short & Homo & Long & G & $\mathrm{P}$ \\
\hline \multicolumn{7}{|c|}{ (a) Tested against expected ratio of 1 homostyle: 1 long } \\
\hline S16L $\times$ Mhomo-H & $\left(s s \times S^{H} S\right)$ & 0 & 12 & 30 & 7.97 & 0.005 \\
\hline S4L $\times$ Mhomo-H & $\left(s S \times S^{H} S\right)$ & 1 & 24 & 44 & 5.97 & 0.02 \\
\hline K21L $\times$ Mhomo-H & $\left(s S \times S^{H} S\right)$ & 0 & 12 & 26 & 5.28 & 0.02 \\
\hline $\mathrm{K} 12 \mathrm{~L} \times$ Mhomo-H & $\left(s S \times S^{H} S\right)$ & 0 & 5 & 9 & 1.16 & 0.28 \\
\hline Pooled & & 1 & 53 & 109 & 19.76 & $<0.001$ \\
\hline Heterogeneity & & - & - & - & 0.62 & 0.89 \\
\hline \multicolumn{7}{|c|}{ (b) Tested against expected ratio of 1 short: 1 long } \\
\hline S16L $\times$ Mhomo-S & $(s s \times S s)$ & 21 & 0 & 27 & 0.75 & 0.39 \\
\hline \multicolumn{5}{|c|}{ Heterogeneity for pooled crosses in (a) vs. S16L $\times$ Mhomo-S } & 1.93 & 0.16 \\
\hline \multicolumn{7}{|c|}{ (c) Tested against expected ratio of 3 homostyle: 1 long } \\
\hline Mhomo-H selfed & $\left(S^{H} S \times S^{H} S\right)$ & 0 & 27 & 9 & 0.0 & 1.0 \\
\hline \multicolumn{7}{|c|}{ (d) Tested against expected ratios of 2 short : 1 homostyle: 1 long } \\
\hline Mhomo-H $\times$ Bry & $\left(S^{H} \times S s\right)$ & 6 & 4 & 5 & 0.71 & 0.70 \\
\hline Bry $\times$ Mhomo-H & $\left(S S \times S^{H} S\right)$ & 4 & 5 & 2 & 2.16 & 0.34 \\
\hline Pooled & & 10 & 9 & $\overline{7}$ & 1.65 & 0.44 \\
\hline Heterogeneity & & - & - & - & 1.22 & 0.54 \\
\hline
\end{tabular}

Comparison of observed and expected morph ratios for crosses involving a homostylous mutant of T. subulata $\times$ krapovickasii (Mhomo-H). Putative parental genotypes are provided in parentheses. The G-statistic for goodness of fit and heterogeneity tests is provided.

(Mhomo-S) upon which it arose. It differs in style length and has reduced pollen fertility (Table 2, Figure 2a, b). Homostyled flowers are fully self-compatible with pollen tubes reaching the base of the styles in all selfpollinations (Table 3). Pollen tubes always reach the base of styles when homostyled flowers are pollinated by pollen from short-styled plants, but pollen from longstyled plants is inhibited (Table 3). Pollen tubes of Mhomo-H grow through the styles of long-styled plants, but are inhibited on short-styled plants. One exception is that pollen of Mhomo- $\mathrm{H}$ has grown to the base of the styles for six of 25 pollinations of a self-compatible short- styled plant (Bry). The mean lengths to which pollen tubes have grown through styles are fully consistent with the results detailed above (Table 3 ).

\section{Inheritance of homostyly for Mhomo-H}

Mhomo-H was backcrossed to two long-styled plants of T. subulata (S16L and S4L) and T. krapovickasii (K12L and K21L). Only long-styled and homostyled progeny occurred (with one exception). The morph ratios, however, yielded a significant deficiency of homostyled progeny (Table 4a). We crossed the nonmutant short-styled plant, 
Table 5 Simultaneous segregation at Aco-1 and the distyly locus

(a) $B R Y \times M h o m o-H$ and reciprocal (not used in recombination frequency estimates)

\begin{tabular}{lrrrc} 
& \multicolumn{4}{c}{ Aco-1 } \\
Morphotype \\
Short & $F F$ & $F M$ & FS & MS \\
Homostyle & 0 & 0 & 8 & 2 \\
Long & 0 & 9 & 0 & 0 \\
Total & 7 & 0 & 0 & 0 \\
Goodne & 7 & 9 & 8 & 2
\end{tabular}

Goodness of fit to 1:1:1:1 ratio, $G_{3 \mathrm{df}}=5.50, P=0.14$

(b) Pooled backcrosses (S16L, S4L, K12L, K21L × Mhomo-H)

Aco-1 genotype

FM $\quad F F$

Homostyle

Long

Total

$\begin{array}{rr}49 & 0 \\ 0 & 100\end{array}$

Goodness of fit to 1:1 ratio, $G_{1 \mathrm{df}}=17.8, P<0.001$

$G_{\text {heterogeneity, } 3 \mathrm{df}}=0.74, P=0.86$

$r=0.007 \pm 0.007$

(c) Krp12LMhom-4 $\mathrm{H}$ selfed and Mhomo-H selfed pooled

\begin{tabular}{lrcc} 
& \multicolumn{3}{c}{ Aco-1 genotype } \\
Homostyle & $F F$ & FM & $M M$ \\
Long & 3 & 38 & 22 \\
Total & 9 & 3 & 0 \\
Coo & 12 & 41 & 22
\end{tabular}

Goodness of fit to $1: 2: 1$ ratio, $G_{2}=3.64, P=0.16$

$G_{\text {heterogeneity, } 2 \mathrm{df}}=5.15, P=0.08$

$r=0.096+0.035$

(d) $S 16 L \times$ Mhbry-9S

$\begin{array}{lcc} & \text { Aco-1 } & \text { genotype } \\ & F M & F S \\ \text { Short } & 5 & 128 \\ \text { Homostyle } & 35 & 1 \\ \text { Total } & 40 & 129 \\ \text { Goodness of fit to } 1: 1 \text { ratio, } G_{1 \mathrm{df}}=49.3, P<0.001 \\ r=0.0355+0.014 \\ \begin{array}{l}\text { Joint recombination frequency, } r=0.031 \pm 0.009, \chi^{2} \text { heterogeneity, } 3 \mathrm{df} \\ =11.9, P=0.008\end{array}\end{array}$

$F, M$ and $S$ are three alleles segregating at the Aco- 1 locus. Goodness of fit tests to expected ratios at the Aco- 1 locus are provided. Where crosses were pooled, a heterogeneity test is provided. Maximum likelihood estimates of the recombination frequency, $r \pm \mathrm{SE}$ are provided. Where no recombinants were observed, $r$ was estimated upon the assumption that the next individual to be assayed would have been a recombinant. A joint estimate of the recombination frequency was obtained following Allard (1956).

Mhomo-S, to S16L. There was a deficiency of short-styled plants among the progeny of this cross, but the ratio did not differ significantly from 1 short: 1 long nor did the ratio differ from the frequency of homostyled to longstyled progeny in the previous crosses to Mhomo-H $\left(G_{\text {heterogeneity }}=1.93, \mathrm{df}=1\right.$; Table $\left.4 \mathrm{~b}\right)$. Progeny produced by self-pollinating Mhomo-H or crossing it to a shortstyled plant (Bry) did not differ significantly from expected ratios (Table 4c, d). Note that the single shortstyled plant observed in the cross $\mathrm{S} 4 \mathrm{~L} \times$ Mhomo- $\mathrm{H}$ is not likely to be a pollen or seed contaminant as it carries the Aco- $1^{M}$ allele (see below).

We assayed a number of progeny (above) for their Aco-1 genotypes. The isozyme data showed aberrant ratios comparable to those at the distyly locus. All longstyled progeny from four crosses were $A c o-1^{F} / A c o-1^{F}$ homozygotes, while homostyled progeny (and the single short-styled plant) were $A c o-1^{F} / A c o-1 M$ heterozygotes
(Table 5b). Some progeny exhibiting recombination between the distyly and Aco-1 loci were obtained in additional crosses (Table 5c, d). Estimates of the recombination frequency between Aco- 1 and the distyly locus for various crosses ranged from 0.007 to 0.096 with a joint estimate of $0.031 \pm 0.009$ (Table 5). This estimate is comparable to recombination frequencies estimated by Athanasiou and Shore (1997).

To determine whether phenotypic ratios might stabilise in later generations, we selfed and crossed two progeny that were obtained from crossing the mutant Mhomo-H to long-styled plants of T. krapovickasii. Selfing resulted in ratios that did not deviate from the expected three homostyled: one long-styled progeny, and in fact, there is a nonsignificant excess of homostyled progeny (Table 6a). Backcrossing the same plants to T. krapovickasii also yielded ratios that did not differ statistically from the 1 homostyled: 1 long-styled expected ratios (Table 6b).

To investigate the phenotype of plants carrying both the $S$ allele and the putative mutant $S^{H}$ allele, we assayed plants from the cross of Mhomo- $\mathrm{H} \times$ Bry (and reciprocal) for their genotypes at the Aco-1 locus. In the absence of recombination between the distyly locus and Aco-1, progeny that are $A c o-1^{M} / A c o-1^{S}$ should be heterozygous, $S / S^{H}$, at the distyly locus. Two such short-styled progeny were obtained (Table 5a). We crossed these plants (Mhbry-9S and Mhbry-14S) to a long-styled plant (S16L), and scored a number of progeny. Only shortstyled and homostyled progeny emerged from these crosses (Table 6c), revealing that the parental plants were indeed $S / S^{H}$ at the distyly locus and demonstrating that the dominance hierarchy was $S>S^{H}>s$.

\section{Aberrant ratios and reciprocal effects}

The ratios of short-styled to homostyled progeny from the crosses of Mhbry-9S and Mhbry-14S to S16L are highly aberrant showing a significant deficiency of homostyled plants (Table 6c). To test whether the aberrant ratios are a result of problems associated with male vs female gamete production and/or function, we carried out a reciprocal cross for one of these plants (Mhbry-9S $\times$ S16L). We also grew out additional samples of progeny to verify our initial observations of distorted ratios (Athanasiou et al, 2003). All three sets of progeny obtained when Mhbry-9S or Mhbry-14S were the pollen parents show a significant deficiency of homostyled progeny and there was no significant heterogeneity among the crosses (Table 6c, i). When the maternal parent was heterozygous $S / S^{H}$, the ratios were not as deviant for the first set of progeny grown out and fully met the expected ratios for the second grow out (Table $6 \mathrm{c}$, ii). These two sets of progeny do show significant heterogeneity (Table $6 c$, ii, $G_{\text {heterogeneity }}=7.14, P<0.008$ ), however, the bulk of the heterogeneity in morph ratios for the five sets of progeny occurs among the reciprocals (Table $6 \mathrm{c}, G_{\text {heterogeneity }}=57.17, P<0.001$ ).

\section{Viability of $S^{H} / S^{H}$ homozyotes}

To determine whether the homozygous mutant genotype, $S^{H} / S^{H}$, is viable, we verified that it was possible to obtain plants with an $S^{H} / S^{H}$ genotype. To do this, we first assayed selfed progeny of the plant K12Lmho- $4 \mathrm{H}$ for their genotypes at Aco-1. In the absence of recombination, Aco- $1^{M} / A c o-1^{M}$ progeny should be homozygous for 
Table 6 Inheritance of homostyly in later generation crosses

\begin{tabular}{|c|c|c|c|c|c|c|}
\hline & Cross & Short & Homo & Long & G & $\mathrm{P}$ \\
\hline \multicolumn{7}{|c|}{ (a) ' $F_{2} s^{\prime}$ tested against expected ratio of 3 homostyle: 1 long } \\
\hline K12Lmho-4 H selfed & $\left(S^{H_{S}} \times S^{H_{S}}\right)$ & 0 & 65 & 16 & 1.25 & 0.26 \\
\hline K12Lmho-3 H selfed & $\left(S^{H} S \times S^{H} S\right)$ & 0 & 18 & 3 & 1.45 & 0.23 \\
\hline Pooled & & 0 & 83 & 19 & 2.36 & 0.13 \\
\hline Heterogeneity & & & & & 0.35 & 0.55 \\
\hline \multicolumn{7}{|c|}{ (b) 'Backcrosses' into T. krapovickasii genetic background, tested against expected ratio of 1 homostyle: 1 long } \\
\hline $\mathrm{K} 12 \mathrm{~L} \times \mathrm{K} 12 \mathrm{Lmho}-4 \mathrm{H}$ & $\left(s S \times S^{H} S\right)$ & 0 & 16 & 10 & 1.40 & 0.24 \\
\hline $\mathrm{K} 12 \mathrm{~L} \times \mathrm{K} 12 \mathrm{Lmho}-3 \mathrm{H}$ & $\left(s S \times S^{H} S\right)$ & 0 & 41 & 36 & 0.32 & 0.57 \\
\hline Pooled & & 0 & 57 & 46 & 1.18 & 0.28 \\
\hline Heterogeneity & & & & & 0.55 & 0.46 \\
\hline \multicolumn{7}{|c|}{$\begin{array}{l}\text { (c) 'Backcrosses' into T. subulata genetic background, tested against expected ratio of } 1 \text { short : } 1 \text { homostyle } \\
\text { (i) Pollen parent heterozygous, SS }\end{array}$} \\
\hline S16L $\times$ Mhbry-9S & $\left(s s \times S^{H} S\right)$ & 133 & 36 & 0 & 59.22 & $<0.001$ \\
\hline S16L $\times$ Mhbry-9S ${ }^{b}$ & $\left(s S \times S^{H} S\right)$ & 95 & 13 & 0 & 70.30 & $<0.001$ \\
\hline S16L $\times$ Mhbry-14S & $\left(s S \times S^{H} S\right)$ & 83 & 23 & 0 & 36.06 & $<0.001$ \\
\hline Pooled & & 311 & 72 & 0 & 160.07 & $<0.001$ \\
\hline $\begin{array}{l}\text { Heterogeneity } \\
\text { (ii) Ovule parent heterozygous, } \mathrm{SSH}\end{array}$ & & - & - & - & 4.84 & 0.09 \\
\hline Mhbry-9S $\times$ S16L & $\left(S^{H} S \times s S\right)$ & 59 & 29 & 0 & 10.44 & $<0.001$ \\
\hline Mhbry-9S $\times$ S16L ${ }^{b}$ & $\left(S^{H} S \times s S\right)$ & 121 & 118 & 0 & 0.01 & 0.95 \\
\hline Pooled & & 180 & 147 & 0 & 3.34 & 0.07 \\
\hline Heterogeneity & & - & - & 0 & 7.14 & 0.008 \\
\hline Pooled reciprocals & & 491 & 219 & 0 & 106.91 & $<0.001$ \\
\hline Heterogeneity comparing pooled reciprocals & & & - & - & 57.17 & $<0.001$ \\
\hline Heterogeneity for all 5 crosses & & - & - & - & 69.14 & $<0.001$ \\
\hline
\end{tabular}

Segregation ratios, goodness of fit and heterogeneity tests are provided. Putative parental genotypes are provided in parentheses.

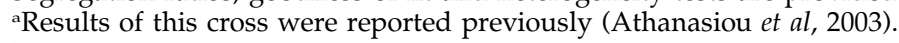

bSecond grow out of additional progeny from these crosses.

the mutant allele and we obtained a number of these plants. We test-crossed three of these progeny to a longstyled plant and scored morph frequency. All progeny were homostyled (with samples sizes of $n=12, n=47$, $n=54$ progeny for the crosses) revealing that the parental plants were indeed homozygous $S^{H} / S^{H}$, and the mutant allele does not result in lethality when homozygous. The probability that the parental plants were not homozygous is less then $3.0 \times 10^{-8}$ for a sample size of $n=12$, and considerably smaller for the larger sample sizes. The occurrence of three homostyled: one long-styled ratios following self-pollination also provides evidence for viability of the $S^{H} / S^{H}$ genotype (Table 6a).

\section{Reversion events}

Periodically during cultivation of the Mhomo-H mutant, we have noticed the appearance of short-styled flowers on some of the rooted cuttings. In some cases, a succession of short-styled flowers appear on a shoot for a few days, and subsequently homostyled flowers are again produced. During one of these episodes of reversion to the short-styled phenotype, we crossed the revertant short pollen onto long-styled plants of both T. subulata (S16L) and T. krapovickasii (K21L). Progeny were long- or short-styled, with the exception of two homostyled progeny. The pooled ratios (40 short-styled: 54 long-styled: two homostyled, $G_{\text {pooled }}=1.54 \mathrm{~ns}$, $G_{\text {heterogeneity }}=0.10 \mathrm{~ns}$ ) did not deviate from 1:1 (homostyled progeny were treated as short-styled plants for the goodness of fit test).

Rooted cuttings of the mutant and nonmutant branches often take on a novel phenotype where the apical meristems are malformed, and flowers are poorly developed, open prematurely, and the shoots may eventually stop flowering. We performed pollinations using pollen of the malformed flowers and crossed them onto a long-styled plant (S16L). We obtained a significant excess of homostyled progeny relative to the 1 longstyled: 1 homostyled expected ratio (1 short-styled: 5 long-styled: 18 homostyled, $G=8.71, P<0.003$, the shortstyled plant was treated as homostyled for the goodness of fit test).

\section{Potential causes of aberrant ratios}

To investigate the possible causes of aberrant ratios, we focussed on the plant Mhbry-9S which shows extremely aberrant ratios as a pollen parent and is genotypically $S / S^{H}$ at the distyly locus. We included 'control' plants (Bry, S16L) involved in its parentage, and/or used in crosses with Mhbry-9S. Mhbry-9S has a mean pollen fertility of $89.9 \pm 0.2 \%$, which is significantly less $\left(F_{2,5}=11.2, P<0.05\right)$ then that of Bry $(96.7 \pm 0.1 \%)$ and S16L $(96.0 \pm 0.2 \%)$. This difference in pollen fertility is, however, insufficient to account for the aberrant segregation ratios. As a pollen parent crossed onto S16L, Mhbry9S does not differ in mean number of seeds sired compared with the control short-styled plant Bry (Table 7). This suggests that seed siring cannot account for the aberrant ratios. As an ovule parent, Mhbry-9S sets significantly fewer seeds when pollinated by S16L compared with Bry (Table 7). For all crosses, the numbers of aborted seeds is less than one per pollination and there are no significant differences among crosses (Table 7). Mhbry-9S had significantly greater numbers of unferti- 
Table 7 Possible causes of aberrant segregation ratios for crosses involving Mhbry-9S

\begin{tabular}{lccccc}
\hline Cross & $\mathrm{N}$ & Seeds & Aborted seeds & Unfertilised ovules & Percent germination \\
\hline S16L $\times$ Mhbry-9S & 13 & $25.7(7.9)^{\mathrm{a}}$ & $0.4(0.6)$ & $9.7(2.6)^{\mathrm{a}}$ & $19.0(11.5)^{\mathrm{a}}$ \\
Mhbry-9S $\times$ S16L & 13 & $16.8(5.2)^{\mathrm{b}}$ & $0.5(0.9)$ & $53.5(13.6)^{\mathrm{b}}$ & $7.1(3.7)^{\mathrm{a}}$ \\
S16L $\times$ Bry & 13 & $25.0(6.7)^{\mathrm{a}}$ & $0.2(0.6)$ & $1.1 .3(4.6)^{\mathrm{a}}$ & $33.0(9.3)^{\mathrm{b}}$ \\
Bry $\times$ S16L & 13 & $33.8(7.4)^{\mathrm{c}}$ & $0.5(1.1)$ & $108.1^{*}$ & $41.0(5.5)^{\mathrm{a}, \mathrm{c}}$ \\
$F$ & & $13.2^{*}$ & $0.5 \mathrm{~ns}$ & $12.2^{\mathrm{b}, \mathrm{c}}$ \\
\hline
\end{tabular}

Mean (SD) numbers of seeds, aborted seeds, unfertilised ovules and percent germination for various crosses to explore the possible causes of aberrant segregation ratios. F-values for one way ANOVAs are provided. Means with the same superscript do not differ based upon Scheffe's test. *Percent germination data are based upon four pots per cross each containing 50 seeds.

Table 8 Morphological measurements for T. scabra and the Drh mutant homostyle

\begin{tabular}{lcccc}
\hline & $\mathrm{N}$ & Pollen length $(\mu \mathrm{m})$ & Style length $(\mathrm{mm})$ & Stamen length $($ mm) \\
\hline Drh & 5 & $88.3(1.7)^{\mathrm{a}}$ & $10.5(0.6)^{\mathrm{a}}$ & $12.8(0.7)^{\mathrm{a}}$ \\
Short & 10 & $88.4(3.9)^{\mathrm{a}}$ & $6.3(0.5)^{\mathrm{b}}$ & $13.5(0.7)^{\mathrm{a}}$ \\
Long & 18 & $75.8(1.8)^{\mathrm{b}}$ & $11.2(0 .)^{\mathrm{a}}$ & $9.3(0.7)^{\mathrm{b}}$ \\
F-value & & $92.0^{* * *}$ & $212.9^{* * *}$ & $131.6^{* * *}$ \\
\hline
\end{tabular}

***P<0.001.

Mean (SD) pollen size, style and stamen lengths for the Drh homostyle mutant and long- and short-styled plants of autotetraploid T. scabra. Long-styled plants measured were progeny from the cross of Drh with a long-styled plant from this population. F-values from ANOVA are provided. Means with the same superscript do not differ significantly based upon Scheffe's test.

lised ovules (in concert with its low seed set as an ovule parent), perhaps indicating that a large number of ovules are sterile (Table 7). Finally, seed germination percentages were generally less then 50\%. Seeds of Mhbry-9S, when it was the pollen parent, had the lowest rate of germination $(19.0 \%)$ but this does not differ significantly (perhaps as a result of the small sample size) from the control seeds $(30.5 \%)$, where Bry was the pollen parent (Table 7). As an ovule parent, seeds of Mhbry-9S had the greatest rate of germination $(53.0 \%)$ but this did not differ significantly from the control seeds $(41.0 \%)$ obtained using Bry as an ovule parent (Table 7).

\section{T. scabra autotetraploid homostyle Drh}

Style and stamen length measurements indicate that Drh is a long homostyle (Figure 2c, d; Table 8). Its pollen does not differ in length from that of short-styled plants (Table 8). Compatibility relationships illustrate that Drh is self-compatible (Table 9). As a female parent, Drh sets seeds when pollinated by short-styled plants, but not when pollinated by long-styled plants. As a pollen parent, Drh sets seeds when contributing pollen to long-styled plants, but not to short-styled plants. The Drh mutant, does however, set fewer seeds when selfpollinated (autogamously) or pollinated by short-styled plants compared to long-styled plants (Table 9).

When Drh was crossed to long-styled plants, only long-styled and homostyled progeny occurred, although one plant was short-styled. Phenotypic ratios from these crosses did not differ from a 5 homostyled: 1 long-styled tetrasomic ratio (Table 10a). Pooled results from crosses of the Drh mutant to short-styled plants did not deviate from the expected 6 short-styled: 5 homostyled: 1 longstyled tetrasomic ratio, although there was heterogeneity among the crosses (Table 10b). Selfing the Drh mutant yielded a ratio not different from the expected 35 homostyled: 1 long-styled ratio (Table 10c). These results suggest that the mutant is genotypically $S^{H} S^{H} S S$. We
Table 9 Compatibility relationships for T. scabra and the Drh mutant homostyle

\begin{tabular}{lcc}
\hline Cross & $\mathrm{N}$ & Number of seeds $(S D)$ \\
\hline Drh autogamous & 12 & $9.1(2.8)^{\mathrm{a}}$ \\
Drh $\times$ short & 13 & $9.1(3.7)^{\mathrm{a}}$ \\
Drh $\times$ long & 13 & $0.0(0.0)^{\mathrm{b}}$ \\
Long $\times$ Drh & 15 & $26.5(5.4)^{\mathrm{c}}$ \\
Short $\times$ Drh & 10 & $0.1(0.3)^{\mathrm{b}}$ \\
F-value & & $303.6^{* * *}$ \\
\hline
\end{tabular}

$* * * P<0.001$.

Seed set among crosses of autotetraploid T. scabra, long- and shortstyled plants with the mutant homostyle Drh. The ovule parent is listed first for each cross. ANOVA was performed on logtransformed data. Means with the same superscript do not differ significantly based upon Scheffe's test.

chose two homostyled progeny from the initial cross of the Drh mutant to long-styled plants and backcrossed them to their long-styled parents. The results did not deviate from expected 1 homostyled: 1 long-styled ratio, and indicates that the homostyled plants used in these crosses were genotypically $S^{H}$ SSS (Table 10d).

\section{Discussion}

We have described the inheritance and compatibility behaviour of two homostyled mutants. Both mutants exhibit compatibility behaviour and inheritance patterns consistent with that of most of the homostylous Turnera species previously investigated (Barrett and Shore, 1987; Tamari et al, 2001) and with the hypothesis that a gene complex underlies the inheritance of distyly in Turnera (below). We cannot, however, discount the possibility that an allelic series is responsible for the long-, shortand homostyled phenotypes (Figure 1).

Studies of Primula spp. indicate that the distyly locus is a gene complex composed of three to seven tightly linked 
Table 10 Tetrasomic inheritance of the Drh mutant homostyle

\begin{tabular}{|c|c|c|c|c|c|c|}
\hline \multirow[t]{2}{*}{ Cross } & & \multicolumn{3}{|c|}{ Phenotype frequencies } & \multirow[t]{2}{*}{ G } & \multirow[t]{2}{*}{$\mathrm{P}$} \\
\hline & & Short & Homo & Long & & \\
\hline \multicolumn{7}{|c|}{ (a) Tested against expected ratio of 5 homostyle: 1 long } \\
\hline DR4-1L $\times$ Drh & $\left(\operatorname{sSSS} \times S^{H} S^{H} \mathrm{SS}\right)$ & 0 & 135 & 29 & 0.12 & 0.73 \\
\hline DR4-2L $\times$ Drh & $\left(\operatorname{ssSS} \times S^{H} S^{H} \mathrm{SS}\right)$ & 0 & 58 & 18 & 2.45 & 0.12 \\
\hline DR4-3L $\times$ Drh & $\left(\operatorname{sSSS} \times S^{H} S^{H} S s\right)$ & $1^{\mathrm{a}}$ & 39 & 8 & 0.00 & 1.00 \\
\hline Pooled & & 0 & 232 & 55 & 1.18 & 0.28 \\
\hline Heterogeneity & & - & - & - & 1.39 & 0.50 \\
\hline \multicolumn{7}{|c|}{ (b) Tested against expected ratios of 6 short: 5 homostyle: 1 long } \\
\hline Drh $\times$ DR4-1S & $\left(S^{H} S^{H} \mathrm{SS} \times S s S S\right)$ & 46 & 29 & 4 & 2.68 & 0.26 \\
\hline Drh $\times$ DR4-2S & $\left(S^{H} S^{H} S S \times S S S S\right)$ & 35 & 30 & 14 & 7.09 & 0.03 \\
\hline Pooled & & 81 & 59 & 18 & 2.38 & 0.30 \\
\hline Heterogeneity & & - & - & - & 7.40 & 0.03 \\
\hline \multicolumn{7}{|c|}{ (c) Tested against expected ratio of 35 homostyle : 1 long } \\
\hline Drh selfed & $\left(S^{H} S^{H} \mathrm{SS} \times S^{H} S^{H} \mathrm{SS}\right)$ & 0 & 52 & 1 & 0.18 & 0.67 \\
\hline \multicolumn{7}{|c|}{ (d) Backcross tested against expected ratio of 1 homostyle: 1 long } \\
\hline DR4-1L $\times$ Drh-95H & $\left(s s s S \times S^{H} S S s\right)$ & 0 & 12 & 13 & 0.04 & 0.84 \\
\hline DR4-3L $\times$ Drh-9H & $\left(s s S S \times S^{H} s s s\right)$ & 0 & 37 & 35 & 0.05 & 0.82 \\
\hline Pooled & & 0 & 49 & 48 & 0.01 & 0.92 \\
\hline Heterogeneity & & - & - & - & 0.09 & 0.76 \\
\hline
\end{tabular}

Comparison of observed and expected morph ratios under the assumption of tetrasomic inheritance for crosses involving a homostylous mutant, Drh, of autotetraploid T. scabra. Putative parental genotypes are indicated in parentheses. Goodness of fit and heterogeneity tests are provided.

${ }^{2}$ This plant is short-styled, pollen sterile and its flowers are often malformed. It was treated as a homostyle for the purposes of goodness of fit tests.

genes separable by infrequent recombination (Dowrick, 1956; Lewis and Jones, 1992; Kurian and Richards, 1997). In the simplest gene complex model, the distyly locus is comprised of three tightly linked diallelic loci designated G, P and A (Ernst, 1955; Dowrick, 1956; Ganders, 1979; Richards, 1993) the order of which might differ among Primula species (Dowrick, 1956; Lewis and Jones, 1992; Kurian and Richards, 1997). Style length and its incompatibility are determined by two alternative alleles, $G / g$, pollen size and its incompatibility by $P / p$ and stamen length by $A / a$. The dominant $S$ allele of distyly involves linkage of all dominant alleles in coupling, while the $s$ allele is comprised of the recessive alleles. If we apply this model to Turnera, our data are consistent with the possibility that the $S^{H}$ allele conferring homostyly represents a mutation of the $G$ allele of the gene complex to a recessive form, $g^{*}$. Thus, the $S^{H}$ allele of distyly would be comprised of the alleles $g^{*} P A$ under this model (Figure 1). We believe this model may be appropriate because stamen length, pollen size and pollen incompatibility of both homostyle mutants follow that of the short-styled phenotype, while style length and its incompatibility have been altered to become like the style of the long-styled morph. While we cannot comment on the number and identity of loci contributing to male function (ie the $\mathrm{P}$ and $\mathrm{A}$ loci), our results are consistent with the occurrence of a separately mutable Glocus determining characteristics of the style.

\section{Origin of the homostyle mutants}

Homostyles are thought to arise via recombination within the gene complex determining homostyly in Primula species. Dowrick (1956) suggested that the occurrence of recombinant homostyles in autotetraploid Primula obconica might be attributable to altered positions of chiasmata (relative to diploids) resulting from quadrivalent formation in that species. It is possible that the homostyle of autotetraploid T. scabra (Drh) was the result of meiotic recombination since the mutant appeared as a seedling growing out of the pot of an adult plant. Curiously, the mutant carries two copies of the $S^{H}$ allele and is genotypically $S^{H} S^{H} S S$. We cannot say with certainty how this mutant arose. It is possible that a somatic mutation to homostyly occurred in one of the adult plants under cultivation, which selfed giving rise to the plant we discovered. Another alternative would seem to involve two potentially rare events: a mutation to the homostyle allele, $S^{H}$, coupled with gene conversion of another $s$ allele to an $S^{H}$ allele.

The Mhomo-H mutant clearly did not arise via meiotic recombination as the mutant first appeared on one shoot of an otherwise short-styled plant. The mutation exhibits some instability as evidenced by the infrequent occurrence of revertant short-styled flowers on the mutant as well as the occurrence of short-styled or homostyled progeny for crosses where none were expected.

\section{Aberrant ratios}

Extremely aberrant ratios showing a deficiency of the homostyled phenotype were observed for crosses of the Mhomo-H mutant particularly when the mutant was a pollen parent. The causes of these ratios are unknown but they become more regular for later generation crosses in the T. krapovickasii genetic background and are less extreme in a T. subulata genetic background when the Mhbry-9S heterozygote is the ovule rather than the pollen parent (Table 6). The aberrant ratios also occur at two isozyme loci linked to the distyly locus (Table 5; Athanasiou et al, 2003). 
Aberrant ratios appear to be a frequent occurrence at many loci when genetic studies are carried out for interspecific crosses and/or crosses between cultivars (Jenczewski et al, 1997; Xu et al, 1997; Ky et al, 2000; Fishman et al, 2001; Hawkings and Dane, 2001; Lashermes et al, 2001; Lu et al, 2002). In some instances, as many as $50 \%$ of the loci studied show aberrant ratios (Hawkins and Dane, 2001) and the loci may be distributed across a number of linkage groups (Fishman et al, 2001). Aberrant segregation ratios have been attributed to a number of physiological, genetical and environmental factors (Grant, 1975; Xu et al, 1997). They may result from selective abortion of male or female gametes (ie differential transmission of male or female gametes bearing specific genotypes) or preferential fertilisation by gametes of certain genotypes, or via postzygotic selection eliminating specific genotypes or combinations of genotypes ( $\mathrm{Xu}$ et al, 1997; Taylor and Ingvarsson, 2003).

We attempted to determine whether the causes of the aberrant ratios were due to: (1) reduced viability of pollen carrying the mutant $S^{H}$ allele, (2) reduced viability of ovules carrying the $S^{H}$ allele, (3) increased zygotic or embryonic abortion of seeds carrying the $S^{H}$ allele and/ or (4) reduced seed and/or seedling viability of progeny carrying the $S^{H}$ allele. Segregation data from reciprocal crosses revealed that the aberrant ratios were more extreme when Mhbry-9S (the heterozygous parent) was the pollen parent (Table $6 \mathrm{c}$ ). Reduced viability of pollen carrying the mutant allele cannot account for the aberrant ratios, as the difference in pollen fertility (89.9\% vs $96.0 \%)$ is insufficient to account for the marked deviation from 1:1 ratios (ratios are approximately 4 short: 1 homostyle). We explored whether postzygotic mechanisms might contribute to the aberrant ratios. Neither the numbers of seeds sired, nor the percent seeds germinated appear to be sufficient to account for the aberrant ratios. There are no significant differences in numbers of seeds sired (Table 7). While there is a difference in seed germination (30.5 vs 19.0\%), it is not significant and does not appear to be of sufficient magnitude to account for the aberrant ratios. A fourfold reduction in percent germination would be necessary, where progeny carrying the mutant $S^{H}$ allele would account for the reduced germination.

Perhaps the most plausible explanation is that pollen tube competition accounts for the aberrant ratios and that pollen carrying the mutant allele suffers reduced pollen tube growth rates largely in a T. subulata genetic background. This possibility is supported by two pieces of information. First, the difference in segregation ratios when Mhbry-9S is used as a pollen parent (where the ratios are more aberrant) vs ovule parent, is consistent with this hypothesis (Table 6c). Second, the ratios do not deviate from 1: 1 when the nonmutant short-styled plant Mhomo-S (Table 4) or revertant shortstyled flowers are used in crosses. For these latter crosses, the genetic background is identical, while only the possession of the mutant $S^{H} v$ s the nonmutant $S$ allele differs. While aberrant ratios have been observed for crosses of various distylous species, pollen tube competition during compatible crosses does not appear to have been responsible for these ratios, but they have resulted from postzygotic effects (Mather and DeWinton, 1941; Baker, 1975).
Whether an allelic series or a gene complex underlies distyly in Turnera remains unclear. Athanasiou et al (2003) and Tamari and Shore (2004) have provided data showing that the $S$ allele of the distyly locus is responsible for the expression of a gene encoding a polygalacturonase that is linked to but $4.6 \mathrm{cM}$ distal to the distyly locus. The function of this short-style-specific polygalacturonase, which localises to the style transmitting tissue (Khosravi et al, 2003), is currently unknown. Khosravi et al (2004) have recently shown that an $\alpha$ dioxygenase is specific to styles of short-styled plants and the gene encoding it is not linked to the distyly locus. Our data, coupled with those of Athanasiou et al (2003), suggest that distyly in T. subulata may be the result of both a gene complex, as well as genes that exhibit morph-limited expression. This genetic architecture was postulated by Lloyd and Webb (1992) in their study of the evolution of distyly.

\section{Acknowledgements}

We thank Jonathon Labonne and Farnaz Tamari for technical assistance, and two anonymous reviewers for their helpful comments on the manuscript. This work was funded by an NSERC grant to JSS.

\section{References}

Allard RW (1956). Formulas and tables to facilitate the calculation of recombination values in heredity. Hilgardia 24: $235-278$.

Arroyo J, Barrett SCH (2000). Discovery of distyly in Narcissus (Amaryllidaceae). Am J Bot 87: 748-751.

Athanasiou A, Khosravi D, Tamari F, Shore IS (2003). Characterization and localization of short-specific polygalacturonase in distylous Turnera Turneraceae). Am J Bot 90: 675-682.

Athanasiou A, Shore JS (1997). Morph-specific proteins in pollen and styles of distylous Turnera (Turneraceae). Genetics 146: 669-679.

Baker HG (1975). Sporophyte-gametophyte interaction in Linum and other genera with heteromorphic self-incompatibility. In: Mulcahy DL (ed) Gamete Competition in Plants and Animals. North-Holland Publishing Co.: Amsterdam, The Netherlands, pp 191-199.

Barrett SCH, Shore JS (1987). Variation and evolution of breeding systems in the Turnera ulmifolia L. complex (Turneraceae). Evolution 41: 340-354.

Dowrick VPJ (1956). Heterostyly and homostyly in Primula obconica. Heredity 10: 219-236.

Dulberger R (1992). Floral polymorphisms and their functional significance in the heterostylous syndrome. In: Barrett $\mathrm{SCH}$ (ed) Evolution and Function of Heterostyly. Springer-Verlag: New York, pp 41-84.

Ernst A (1955). Self-fertility in monomorphic Primulas. Genetica 27: 91-148.

Fishman L, Kelly AJ, Morgan E, Willis JH (2001). A genetic map in the Mimulus guttatus species complex reveals transmission ratio distortion due to heterospecific interactions. Genetics 159: 1701-1716.

Ganders FR (1979). The biology of heterostyly. NZ J Bot 17: 607-635.

Grant V (1975). Genetics of Flowering Plants. Columbia University Press: New York.

Hawkings LK, Dane F (2001). Linkage mapping in a watermelon population segregating for Fusarium wilt resistance. J Am Soc Hort Sci 126: 344-350.

Jenczewski E, Gherardi M, Bonnin I, Prosperi JM, Olivieri I, Huguet T (1997). Insight on segregation distortions in two 
intraspecific crosses between annual species of Medicago (Leguminosae). Theor Appl Genet 94: 682-691.

Khosravi D, Roshanak J, Shore JS (2003). Immunocytochemical distribution of polygalacturonase and pectins in styles of distylous and homostylous Turneraceae. Sex Plant Reprod 16: 179-190.

Khosravi D, Yang ECC, Siu KWM, Shore JS (2004). High level of $\alpha$-dioxygenase in short styles of distylous Turnera species. Int J Plant Sci (in press).

Kurian V, Richards J (1997). A new recombinant in the heteromorphy ' $\mathrm{S}$ ' supergene in Primula. Heredity 78: 383-390.

Ky CL, Barre P, Lorieux M, Trouslot P, Akaffou S, Louarn J et al (2000). Interspecific genetic linkage map, segregation distortion and genetic conversion in coffee (Coffea sp. Theor Appl Genet 101: 669-676.

Lashermes P, Combes MC, Prakash NS, Trouslot P, Lorieux M, Charrier A (2001). Genetic linkage map of Coffea canephora: effect of segregation distortion and analysis of recombination rate in male and female meioses. Genome 44: 589-596.

Lewis D, Jones DA (1992). The genetics of heterostyly. In: Barrett SCH (ed) Evolution and Function of Heterostyly. Springer-Verlag: New York, pp 129-150.

Lloyd DG, Webb CJ (1992). The evolution of heterostyly. In: Barrett SCH (ed) Evolution and Function of Heterostyly. Springer-Verlag: New York, pp 151-178.

Lu H, Romero-Severson J, Bernardo R (2002). Chromosomal regions associated with segregation distortion in maize. Theor Appl Genet 105: 622-628.

Mather K, DeWinton D (1941). Adaptation and counter adaptation of the breeding system in. Primula. Ann Bot 5: 297-311.
Richards AJ (1993). Primula. Timber Press: Portland, Oregon, pp 45-67.

Richards AJ (1997). Plant Breeding Systems, 2nd edn. Chapman \& Hall: London.

SAS (1996). SAS/STAT User's Guide. Release 603 ed. SAS Institute Inc: Cary, NC.

Shore JS (1991a). Tetrasomic inheritance and isozyme variation in Turnera ulmifolia vars. elegans Urb and intermedia Urb (Turneraceae). Heredity 66: 305-312.

Shore JS (1991b). Chromosomal evidence for autotetraploidy in Turnera ulmifolia. Can J Bot 69: 1302-1308.

Shore JS, Barrett SCH (1985). The genetics of distyly and homostyly in Turnera ulmifolia L. (Turneraceae). Heredity 55: 167-174.

Shore JS, Barrett SCH (1986). Genetic modifications of dimorphic incompatibility in the Turnera ulmifolia L. complex (Turneraceae). Can J Genet Cytol 28: 796-807.

SPSS (1997). Version 8.0. SPSS Inc.: Chicago, Illinois.

Tamari F, Athanasiou A, Shore JS (2001). Pollen tube growth and inhibition in distylous and homostylous Turnera and Piriqueta (Turneraceae). Can J Bot 79: 578-591.

Tamari F, Shore JS (2004). Distribution of style and pollen polygalacturonases among distylous and homostylous Turnera and Piriqueta spp. (Turneraceae). Heredity 92: 380-385.

Taylor DR, Ingvarsson PK (2003). Common features of segregation distortion in plants and animals. Genetica 117: 27-35.

Xu Y, Zhu L, Xiao J, Huang N, McCouch SR (1997). Chromosomal regions associated with segregation distortion of molecular markers in $\mathrm{F}_{2}$, backcross, double haploid, and recombinant inbred populations in rice (Oryza sativa L.). Mol Gen Genet 253: 535-545. 